Підлинна Р. П., radmila2008@ukr.net, ORCID ID:0000-0001-6886-5834, д.е.н., доч., професор кафедри обліку та оподаткування, Ужгородський торговельно-економічний інститут Київського національного економічного університету, м. Ужгород

\title{
ЗАГОСТРЕННЯ СОЦІАЛЬНИХ ПРОБЛЕМ В УКРАЇНІ У СВІТЛІ КАРАНТИННИХ ОБМЕЖЕНЬ
}

\begin{abstract}
Анотація. Ключовими проблемами, щзо суттєво обмежують зростання конкурентоспроможності системи соціального захисту в Украӥні, є прогалини в державному регулюванні та недосконалості інфраструктури соціальної сфери, щзо визначає об 'єктивну потребу в посиленні соціальних функцій держави. Статтю присвячено дослідженню впливу карантинних обмежень, викликаних пандемією Covid-19, на розвиток кризи сочіального розвитку в Україні та виявленню можливих шляхів ї̈ подолання. Зазначено, щзо в період кризи спричинені карантинними обмеженнями негативного впливу зазнали такі елементи соціального розвитку, як система медичного обслуговування населення, надання освітніх послуг, громадський транспорт, рекреаційні установи. Вирішення завдань державної політики сочіального захисту запропоновано визначати не лише економічними ресурсами, які може направляти держава на їх здійснення, але і розглядати як найважливіший чинник економічного зростання у посткризовий період відновлення соціально-економічного зростання, оскільки саме завдяки цілеспрямованій соціальній політиці з'являються умови для зростання і реалізації інноваційного потенціалу трудових ресурсів суспільства. Було встановлено, щзо перерозподіл видатків Державного бюджету Украӥни дозволив направити додаткові кошти на соиіальний захист в умовах пандемії, а саме придбання медичних послуг, додаткові виплати працівникам, безпосередньо зайнятим у ліквідації Cоvid-19, або забезпечити засоби до існування, надання фінансової допомоги людям похилого віку та безробітним, субсидування Пенсійного фонду України. Були визначені категорії громадян, які залишились поза увагою програм соиіального захисту: наймані праиівники через приховане безробіття, приватні підприємиі, мігранти, самозайняті особи, молодь, яка вперше вийшла на ринок прачі. Пропонується на державному рівні врегулювати гнучкі формати зайнятості, забезпечити їм повночінні трудові та сочіальні гарантіі. Визначено основні соціальні проблеми дистанційного навчання та відповідні ризики сочіальної нерівності для розвитку людського капіталу. Подальші дослідження доиільно присвятити дослідженню соиіальних аспектів впливу карантинних обмежень на пенсійне забезпечення та доступ до медичних послуг, щзо дозволить виявити можливі інституційні інструменти удосконалення соиіальної політики.
\end{abstract}

Ключові слова: соціальна політика, соціальні гарантії, видатки бюджету, якість життя, безробіття, дистанційне навчання.

Pidlypna R.P., radmila2008@ukr.net, ORCID ID:0000-0001-6886-5834, Doctor of Economics, Associate Professor, Professor of Department of Accounting and Taxation, Uzhgorod Trade and Economic Institute of Kyiv National University of Trade and Economics, Uzhhorod

\section{EXACERBATION OF SOCIAL PROBLEMS IN UKRAINE IN THE LIGHT OF QUARANTINE RESTRICTIONS}

\footnotetext{
Abstract. The key problems that significantly limit the growth of the competitiveness of the social protection system in Ukraine are gaps in state regulation and imperfections and infrastructure of the social sphere, which determines the objective need to strengthen the social functions of the state. The article is devoted to the study of the impact of quarantine restrictions caused by the Covid-19 pandemic on the development of the social crisis in Ukraine and to identify possible ways to overcome it. It is noted that during the crisis, caused by quarantine restrictions, such elements of social development as the system of medical care, provision of educational services, public transport as well as recreational facilities were negatively affected. It is proposed to determine the solution of the tasks of the state social protection policy not only by economic resources that the state can direct on their implementation, but also to consider it as the most important factor of economic growth in the post-crisis period of socio-economic growth because due to purposeful social policy the conditions for growth and implementation of the innovative potential of society's labor resources appear. It was found that the redistribution of expenditures of the State Budget of Ukraine allowed to direct additional funds for social protection in conditions of pandemic, namely the purchase of medical services, additional payments to employees directly employed in overcoming the Covid-19 threat or provide livelihoods, providing financial assistance to the elderly and unemployed, subsidizing the Pension Fund of Ukraine. Categories of citizens who were left
} 


\section{Herald of Lviv University of Trade and Economics. Economic Sciences. № 59, 2020}

out of the attention of social protection programs were identified: employees due to hidden unemployment, private entrepreneurs, migrants, self-employed persons, young people who first entered the labor market. It is proposed to regulate flexible formats of employment at the state level, to provide them with full-fledged labor and social guarantees. The main social problems of distance learning and the corresponding risks of social inequality for the development of human capital are identified. Further research should be focused on the study of social aspects of the quarantine restrictions impact on pensions and access to health services, which will identify possible institutional tools for improving social policy.

Keywords: social policy, social guarantees, budget expenditures, quality of life, unemployment, distance learning.

$$
\begin{aligned}
& \text { JEL Classification: H31, H51, H53, I38, J28 } \\
& \text { DOI: https://doi.org/10.36477/2522-1205-2020-59-02 }
\end{aligned}
$$

Постановка проблеми. Ключовими проблемами, які значною мірою обмежують зростання конкурентоспроможності системи соціального захисту населення в Україні, є прогалини в державному регулюванні та недосконалість та інфраструктури соціальної сфери, що зумовлює об'єктивну потребу посилення соціальних функцій держави. Пандемія Covid-19 спричинила до розвитку кризи соціального розвитку у всьому світі. У деяких аспектах соціального забезпечення умови сьогодні еквівалентні рівням депривації, які востаннє спостерігалися в середині 1980-х років, адже негативного впливу зазнали всі складові елементи соціального розвитку: доходи (через безпрецедентне скорочення економічної діяльності), здоров'я (щоденна значна кількість загиблих і потенційні захворюваність та смертність від дотичних причин) та освіта. Організацією Об’єднаних Націй ще у 1961 році розроблено рекомендації щодо компонентів та індикаторів рівня життя, зокрема здоров'я, харчування, освіти, зайнятості та умов праці, соціального забезпечення та свободи особистості [16]. Міжнародна організація праці наголошує, що соціальна політика кожної держави має спрямовуватися на досягнення добробуту й розвитку населення, а також на заохочення його прагнення до соціального прогресу [7]. Водночас кризові явища, спричинені стрімким погіршенням соціального становища більшої частини населення України в результаті запровадження карантинних обмежень, істотно вплинули на пріоритетність цілей і технології соціальної політики держави. Вона включає не тільки умови і рівень розвитку соціальної сфери, але і соціальний захист людини. 3 одного боку, вирішення багатьох завдань державної політики соціального захисту визначається економічними ресурсами, які може направляти держава на їх здійснення, з іншого, - державну політику соціального захисту можна розглядати як найважливіший чинник економічного зростання, оскільки саме завдяки цілеспрямованій соціальній політиці 3'являються умови для зростання і реалізації інноваційного потенціалу трудових ресурсів суспільства.

Аналіз останніх досліджень і публікацій. Проблемам соціального забезпечення присвячено значну кількість наукових публікацій. Серед найбільш релевантних варто відмітити роботу I. Гнидюка, О. Гайдея, присвячену аналізу розвитку бюджетного фінансування соціальних програм в Україні, визначення його проблем і розроблення шляхів подальшого розвитку [4]. В. Роледерс та Г. Кукель досліджували проблеми і перспективи подальшого реформування та удосконалення фінансового забезпечення соціального захисту населення в Україні [12]. Авторами на основі аналізу видатків на соціальний захист виявлено сучасні проблеми фінансування та окреслено шляхи їх подолання. Також слід відмітити важливість дослідження О. Насібової, яка акцентувала увагу на потенційних джерелах створення фондів фінансових ресурсів системи соціального захисту [11]. Дуже актуальну інформацію надає Є. Яригіна, яка вивчала права сімей із дітьми на соціальний захист в якості складової соціальних прав людини [14]. Дослідження С. Кудлаєнко присвячено механізмам реалізації соціальної політики держави, базованої на концепції всебічного розвитку особистості, центральними елементами якої автор визначає державні соціальні гарантії та державне соціальне забезпечення [6]. Джерелом для подальших наукових розробок стала і стаття I. Свидрук, яка описує проблему експектаційної невідповідності працівників, яка $є$ актуальною в карантинних умовах сьогодення, та пропонує використання низки інструментів соціальнопсихологічної саморегуляції. Інтерес викликає публікація К. Гнатенка, який переконливо доводить, що єдність і диференціація є ключовими принципами соціального забезпечення, які органічно доповнюють одне одного та покладені в основу загального принципу соціальної справедливості, відображаючи наявність єдиних концептуальних засад розвитку права соціального забезпечення, необхідність його сталості, стабільності та універсальності, а також необхідність врахування різних соціальних ризиків і особливостей, потреб та інтересів осіб, які потребують адекватного соціального захисту [3].

Формулювання цілей статті. Основним завданням статті $є$ дослідження впливу карантинних обмежень, викликаних пандемією Covid-19, на розвиток кризи соціального розвитку в Україні та виявлення можливих шляхів їі подолання.

Виклад основного матеріалу. В Україні державне регулювання соціальної сфери покликане забезпечити гідний рівень життя населення [2]. Проголошені в останні роки реформи системи соціального забезпечення значною мірою були 
орієнтовані на неоліберальну модель, що включає скорочення частки видатків на соціальну сферу i перехід на адресні допомоги. Однак в умовах нестійкого соціально-економічного розвитку, притаманного Україні, скорочення соціальних сервісів може зумовлювати зростання соціальної залежності громадян від кризових ситуацій та появу нових соціальних викликів: поширення бідності серед працюючих, зростання рівня безробіття, економічну незахищеність вразливих категорій населення, нерівність у доступі до медичних та освітніх сервісів, ерозію людського капіталу. Проблеми вітчизняної політики соціального захисту під час карантинних обмежень, викликаних пандемією Covid-19, значно актуалізувались. Особливих проблем зазнали системи медичного обслуговування населення, надання освітніх послуг, громадський транспорт, рекреаційні установи. Від цього значно погіршилася якість життя практично усіх категорій громадян, насамперед літніх людей і громадян 3 низьким рівнем доходів. Фінансування соціальних програм для покращення становлення населення було визначено пріоритетним завданням державних інституцій. Проаналізуємо значення показників видатків державного бюджету в Україні у 2015-2019 рр. та перших п'яти місяців 2020 р. (табл. 1).

Як бачимо, впродовж 2015-2019 рр. частка видатків бюджету на соціальний захист та соціальне забезпечення коливалася в межах $17-20 \%$, натомість в умовах пандемії виділення коштів сягнуло $31,4 \%$. Розглядаючи частку всіх витрат соціального спрямування (включаючи видатки на охорону навколишнього середовища, житлово-комунальне господарство, охорону здоров'я, духовний та фізичний розвиток, освіту і власне соціальний захист та соціальне забезпечення), можна побачити аналогічну тенденцію, тобто коливання у 2015-2017 рр. в межах 25-31\%, тоді як у січні-травні 2020 р. цей показник сягнув $42,3 \%$.

Видатки державного бюджету України у 2015-2019 рр. та за січень-травень 2020 р. (млн грн)

\begin{tabular}{|c|c|c|c|c|c|c|c|}
\hline Показники & 2015 & 2016 & 2017 & 2018 & 2019 & $\begin{array}{c}2019 \\
12015 \\
\%\end{array}$ & $\begin{array}{c}2020 \text { (ci- } \\
\text { чень- } \\
\text { травень) }\end{array}$ \\
\hline Усього & 576911,4 & 684743,4 & 839243,7 & 985842 & 1072891,5 & 186,0 & 438375,7 \\
\hline $\begin{array}{l}\text { Загальнодержавні } \\
\text { функції }\end{array}$ & 103116,7 & 117925,6 & 142446,9 & 162949,9 & 168206,5 & 163,1 & 68993,4 \\
\hline $\begin{array}{l}\text { у т.ч. обслуговування } \\
\text { держборгу }\end{array}$ & 84505,4 & 95794,2 & 110456,1 & 115431,2 & 119247,6 & 141,1 & 53796,3 \\
\hline Оборона & 52005,2 & 59348,9 & 74346,2 & 97024 & 106627,7 & 205,0 & 38506,5 \\
\hline $\begin{array}{l}\text { Громадський порядок, } \\
\text { безпека }\end{array}$ & 54643,4 & 71671,1 & 87845 & 116875,6 & 140151,2 & 256,5 & 53912,3 \\
\hline Економічна діяльність & 37135,4 & 31412,3 & 47000,1 & 63600,7 & 72365,1 & 194,9 & 26431,5 \\
\hline $\begin{array}{l}\text { Охорона навколиш- } \\
\text { нього середовища }\end{array}$ & 4053 & 4771,6 & 4739,9 & 5241,2 & 6316,2 & 155,8 & 1415 \\
\hline $\begin{array}{l}\text { Житлово-комунальне } \\
\text { господарство }\end{array}$ & 21,5 & 12,5 & 16,9 & 296,9 & 108 & 502,3 & 8,5 \\
\hline Охорона здоров’я & 11450,4 & 12456,3 & 16729,1 & 22617,9 & 38561,6 & 336,8 & 23956,2 \\
\hline $\begin{array}{l}\text { Духовний та фізичний } \\
\text { розвиток }\end{array}$ & 6619,2 & 4958,9 & 7898,1 & 10107,1 & 9967 & 150,6 & 2687,5 \\
\hline Освіта & 30185,7 & 34825,4 & 41140,2 & 44323,4 & 51657,6 & 171,1 & 19388 \\
\hline $\begin{array}{l}\text { Соціальний захист та } \\
\text { соціальне забезпечен- } \\
\text { ня }\end{array}$ & 103700,9 & 151965,5 & 144478,3 & 163865,6 & 218628,6 & 210,8 & 137844,8 \\
\hline $\begin{array}{l}\text { у т.ч. соціальний за- } \\
\text { хист пенсіонерів }\end{array}$ & 94811,6 & 142586,2 & 133458,6 & 150091 & 182270,1 & 192,2 & 87762,6 \\
\hline $\begin{array}{l}\text { Міжбюджетні транс- } \\
\text { ферти }\end{array}$ & 173980 & 195395,3 & 272602,9 & 298939,7 & 260302 & 149,6 & 65231,9 \\
\hline $\begin{array}{l}\text { Частка витрат на соці- } \\
\text { альний захист у суку- } \\
\text { пних витратах бюдже- } \\
\text { ту }\end{array}$ & 17,98 & 22,19 & 17,22 & 16,62 & 20,38 & 113,4 & 31,44 \\
\hline $\begin{array}{l}\text { Частка всіх витрат } \\
\text { соціального спряму- } \\
\text { вання у сукупних ви- } \\
\text { тратах бюджету }\end{array}$ & 27,05 & 30,52 & 25,62 & 25,00 & 30,31 & 112,1 & 42,27 \\
\hline
\end{tabular}

Джерело: розраховано за даними [9] 
Herald of Lviv University of Trade and Economics. Economic Sciences. № 59, 2020

Основні зміни в програмах соціального захисту, спричинені поширенням Соvid-19 (млн грн)

\begin{tabular}{|l|c|c|c|c|}
\hline \multicolumn{1}{|c|}{ Програма } & $\begin{array}{c}\text { Передбачалося } \\
\text { бюджетом до } \\
\text { пандемії }\end{array}$ & $\begin{array}{c}\text { Передбачено } \\
\text { оновленим } \\
\text { бюджетом }\end{array}$ & \multicolumn{2}{|c|}{ Зміни } \\
\cline { 2 - 5 } & $\begin{array}{l}\text { абс. } \\
\text { Підвищення кваліфікації працівників сис- } \\
\text { теми соціального захисту }\end{array}$ & 0,7 & $-0,7$ & $-100,0$ \\
\hline Житлові субсидії у грошовій формі & 47570 & 39329,5 & -8240 & $-17,3$ \\
\hline $\begin{array}{l}\text { Реалізація пілотного проекту “Розвиток } \\
\text { соціальних послуг” }\end{array}$ & 100 & 10,0 & -90 & $-90,0$ \\
\hline $\begin{array}{l}\text { Компенсація частини витрат на реалізацію } \\
\text { державних програм соцзахисту населення }\end{array}$ & 150 & 10,0 & -140 & $-93,3$ \\
\hline $\begin{array}{l}\text { Фінансове забезпечення виплат пенсій та } \\
\text { покриття дефіциту коштів Пенсійного фо- } \\
\text { нду України }\end{array}$ & 172576 & 202280,4 & +29704 & $+17,2$ \\
\hline $\begin{array}{l}\text { Заходи з соціальної, трудової та професій- } \\
\text { ної реабілітації осіб з інвалідністю }\end{array}$ & 1532,6 & 1195,6 & -337 & $-22,0$ \\
\hline
\end{tabular}

Джерело: розраховано за даними [8]

Концептуальна ідеологія державної політики соціального захисту населення полягає в посиленні державності як головного принципу соціального захисту населення в Україні і може бути реалізована через створення та підтримку конкурентного середовища в системі соціального захисту населення, зниження корупційної складової та частки тіньового сектора в наданні соціальних послуг та гарантій, дебюрократизацію управління системою, відмову від державних регуляторів та обмежувань, що не випливають з об'єктивних потреб державного регулювання соціального страхування. Так, згідно 3 показником людського розвитку Програми розвитку ООН у 2018-2019 рр. Україна посідала 88 місце зі 189 досліджуваних країн за показником людського розвитку [15]. У Декларації соціального прогресу та розвитку зауважено, що міжнародний мир і безпека, з одного боку, та соціальний прогрес і економічний розвиток, - 3 іншого, - знаходяться у тісному взаємозв'язку [14].

Розуміння важливості соціальної сфери продемонструвала Верховна Рада України, ухваливши в квітні 2020 р. зміни до Державного бюджету [1] i створивши Фонд боротьби 3 Covid-19 у розмірі 64,7 млрд грн (табл. 2), кошти якого спрямовуються передусім на соціальний захист громадян:

- закупівлю медичних послуг за програмою державних гарантій медичного обслуговування населення;
- доплати до заробітної плати працівникам, безпосередньо зайнятим на роботах 3 ліквідації Covid-19, та працівникам, які забезпечують життєдіяльність населення та ліквідацію спалахів епідемiї;

- надання грошової допомоги громадянам, зокрема особам похилого віку, у зв'язку з негативними наслідками поширення на території України Covid-19; раїни;

- надання трансферту Пенсійному фонду Ук-

- надання фінансової допомоги Фонду соціального страхування України і Фонду загальнообов'язкового державного соціального страхування України на випадок безробіття.

Всього видатки Міністерства соціальної політики було скорочено на 9,8 млрд грн (8,3\%), а видатки Пенсійного фонду - збільшено на 29,7 млрд грн (17,2\%). Такі зміни фактично припиняють державну підтримку багатьох соціальних ініціатив, що негативно вплине на розвиток соціальної сфери. Для більш повного розуміння ситуації 3 державним фінансуванням соціальної сфери варто розглянути структуру видатків бюджету у першій половині 2020 р. 


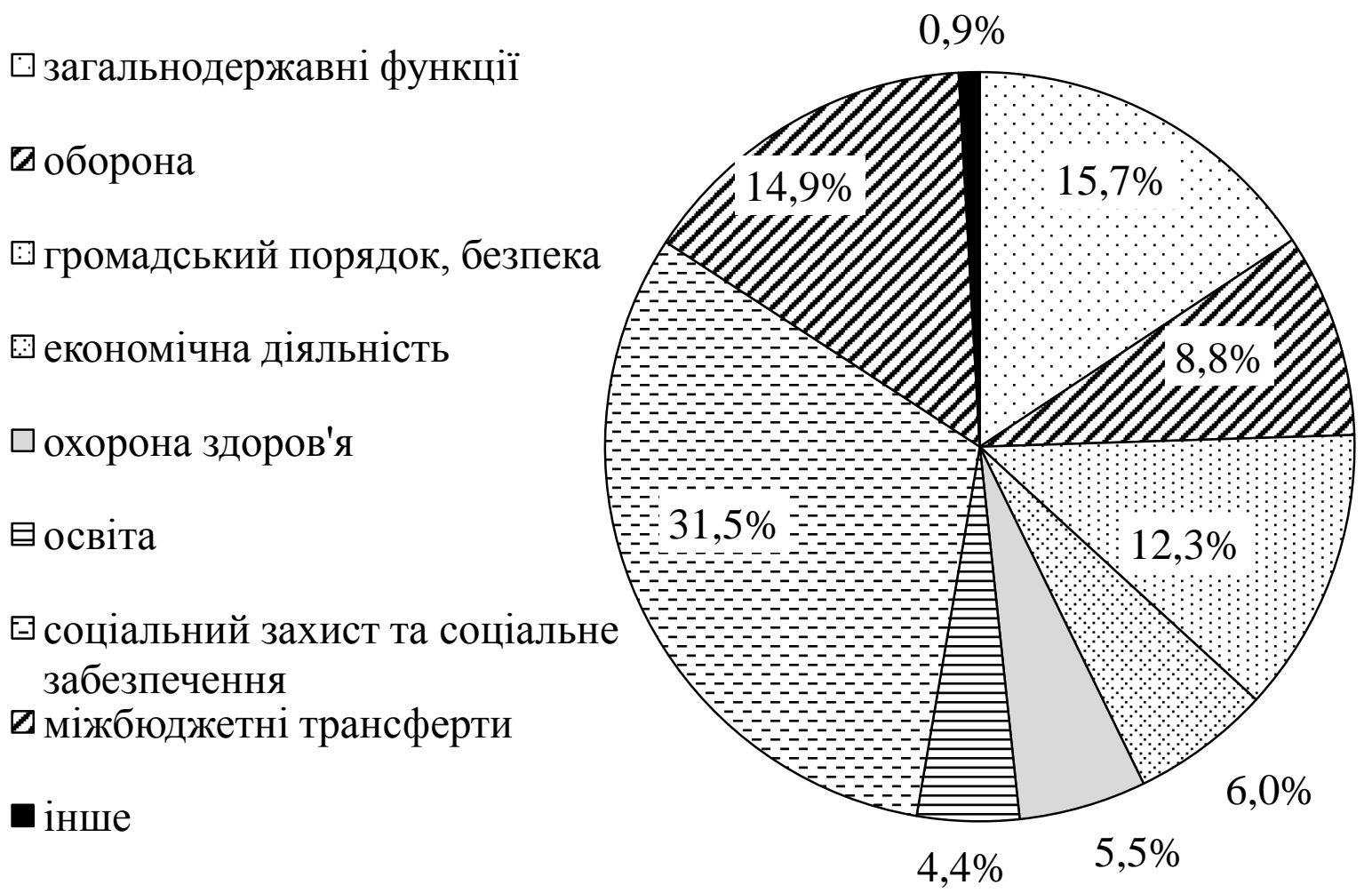

Рис. 1. Структура видатків Державного бюджету України за функціональною класифікацісю у першій половині 2020 р.

Джерело: розраховано за даними [9]

Рівень безробіття в Україні у 2015-2019 рр. та у І кварталі 2020 р.

(тис. осіб)

\begin{tabular}{|l|c|c|c|c|c|c|c|}
\hline \multicolumn{1}{|c|}{ Показник } & 2015 & 2016 & 2017 & 2018 & 2019 & $\begin{array}{c}2019 / \\
2015, \%\end{array}$ & $\begin{array}{c}\text { I кв. } \\
2020\end{array}$ \\
\hline Всього населення & 42760,5 & 42584,5 & 42386,4 & 42153,2 & 41902,4 & 98,0 & 41830,6 \\
\hline $\begin{array}{l}\text { Економічно активне } \\
\text { населення }\end{array}$ & 17396 & 17303,6 & 17193,2 & 17296,2 & 17381,8 & 99,9 & 17329,9 \\
\hline Зайняте населення & 15742 & 15626,1 & 15495,9 & 15718,6 & 15894,9 & 101,0 & 15781,3 \\
\hline $\begin{array}{l}\text { Безробітне населен- } \\
\text { ня }\end{array}$ & 1654 & 1677,5 & 1697,3 & 1577,6 & 1486,9 & 89,9 & 1548,6 \\
\hline Рівень безробіття, \% & 9,5 & 9,7 & 9,9 & 9,1 & 9,6 & 101,1 & 8,9 \\
\hline $\begin{array}{l}\text { Зареєстрованих } \\
\text { безробітних }\end{array}$ & 461,1 & 407,2 & 352,5 & 341,7 & 338,2 & 73,3 & 349,4 \\
\hline
\end{tabular}

Джерело: розраховано за даними [5]

Слід, однак, зазначити, що погіршення соціального становища багатьох громадян залишилося поза увагою програм соціального захисту. У зв'язку 3 введенням карантинних обмежень значного погіршення зазнали соціальні права найманих працівників у більшості сфер економіки, найбільше - у сферах транспортного обслуговування, туризмі, надання послуг гостинності та у сфері ресторанного господарства. Для покращення ситуації Урядом було розроблено рекомендації для роботодавців щодо дотримання норм чинного трудового законодавства відносно працівників, які працюють віддалено або перебувають у неоплачуваній відпустці.
Зазначимо, що можливість дистанційної роботи дозволила багатьом підприємствам уникнути скорочення виробництва (і кадрів), однак у багатьох випадках спричинила погіршення ментального благополуччя працівників. Окрім того, фактично необмежений термін перебування у відпустці без збереження заробітної плати на період карантину можна вважати прихованим безробіттям (табл. 3), під час якого формально працевлаштовані, але тимчасово не працюючі громадяни не отримують допомогу, передбачену у випадку безробіття.

Попри звільнення підприємців та самозайнятих громадян від сплати Єдиного соціального внеску 
під час карантинних обмежень, для цієї категорії населення також не було передбачено заходів матеріальної підтримки в умовах відсутності доходів через тимчасову неможливість здійснювати підприємницьку діяльність. Рівень безробіття значно зріс також завдяки поверненню понад 100 тис. трудових мігрантів, які не мають роботи всередині країни [8]. Отож, кількість безробітних в Україні під час карантинних обмежень збільшилася фактично на 500-700 тисяч людей.

Відновлення економічного зростання після пандемічної кризи потребуватиме соціального діалогу між урядом, роботодавцями та працівниками для забезпечення гідних умов праці та комплексної соціальної допомоги тих, хто втратив роботу внаслідок кризи. Необхідно розробити заходи підтримки для найбільш вразливих груп: літніх людей, мігрантів, молоді, яка вперше виходить на ринок праці, та самозайнятих громадян. Також доцільно на державному рівні врегулювати гнучкі формати зайнятості, забезпечити для них повноцінні трудові і соціальні гарантії.

Оцінюючи виклики перед соціальною сферою в Україні, спричинені пандемічними обмеженнями, слід зупинитися на соціальних проблемах в освіті. Карантин для українських учнів та студентів було оголошено ще в березні 2020 р., згодом навчальні заклади запровадили дистанційне навчання і дотепер залишається не до кінця зрозумілим, чи почнеться новий учбовий рік у звичному режимі. Звичайно, дистанційне навчання до певної міри забезпечує неперервність освітнього процесу, надаючи школярам і студентам можливість ознайомлення 3 навчальним матеріалом. Однак, зважаючи на значну соціальну нерівність у доступі різних верств населення до швидкісного якісного Інтернету та інших сучасних технологій, зростає ризик поглиблення нерівностей в доступі до освіти. Значний соціальний негативний відклик у соцмережах свідчить про неспроможність більшості українських навчальних закладів організовувати онлайн-заняття 3 відеозв'язком. У невеликих містах і сільській місцевості дистанційне навчання здебільшого обмежувалося самостійним опануванням навчальних матеріалів і виконанням отриманих від вчителів завдань. За даними Міністерства цифрової інформації, у 2019 році рівень покриття Інтернетом в Україні сягав 70\% [10]. Нерівномірний доступ до швидкісного покриття, різна готовність батьків допомагати дітям 3 організацією дистанційного навчання, брак сучасної техніки, а також різний рівень комп'ютерної грамотності не сприяли якісному опануванню знаннями багатьох українських дітей. Також не було враховано специфіку учнів 3 особливими освітніми потребами та дітей $з$ соціально малозахищених сімей. Що стосується навчальних закладів вищої освіти, то лише в окремих 3 них дистанційне навчання було організовано на сучасних інтернет-платформах 3 повноцінними лекціями і семінарами в режимі онлайн, натомість частина закладів обмежилася надсиланням завдань студентам, що фактично можна розцінювати як перехід до самоосвіти.
За таких умов скорочення видатків на фінансування української школи, згортання реформ у сфері освіти можуть призвести до погіршення якості освіти, а у довгостроковій перспективі - до зниження якості людських ресурсів. Отож, виникає нагальна потреба в інституційному зменшенні цифрової нерівності, обладнанні сільських шкіл сучасною технікою та швидкісним Інтернетом.

Раціоналізація соціальних видатків у структурі бюджету може стати каталізатором економічного зростання, оскільки вони є вкладеннями у людський капітал. Тому, на нашу думку, необхідно:

- збільшити масштаби фінансування заходів охорони здоров'я;

- здійснити запровадження страхової медицини;

- удосконалити систему менеджменту в медичних закладах;

- інтенсифікувати процес переходу здійснення діяльності на засадах комерційного розрахунку;

- відповідно до світових стандартів розробити державні стандарти мінімальних норм надання безоплатної медичної допомоги;

- здійснити розширення обсягів фінансування сфери освіти шляхом:

- фінансового забезпечення фундаментальних досліджень;

- розроблення та запровадження механізму надання освітніх кредитів;

- оптимізувати бюджетні витрати на соціальний захист та соціальне забезпечення для фінансування соціальних гарантій на рівні світових стандартів.

Висновки і перспективи подальших досліджень у даному напрямі. Концептуальна ідеологія державної політики соціального захисту населення в Україні полягає в посиленні державності як головного принципу соціального захисту населення. В умовах нестійкого соціально-економічного розвитку скорочення соціальних програм призвело до поширення бідності, зростання безробіття, економічної незахищеності населення, нерівності у доступі до освітніх послуг. Попри значну переорієнтацію Державного бюджету в соціальному напрямку, поза увагою програм соціального захисту залишилося погіршення соціального становища багатьох громадян, зокрема найманих працівників у більшості сфер економіки, які зіткнулися з проблемою вимушеного перебування у відпустці без збереження заробітної плати, яке за суттю можна вважати прихованим безробіттям. Соціальні проблеми в освіті загострилися під час карантину для учнів та студентів, спричинивши ризик поглиблення нерівностей у доступі до освіти. При цьому передбачене скорочення видатків на освіту може призвести до погіршення іiі якості, а у довгостроковій перспективі - до зниження якості людських ресурсів. Раціоналізація соціальних видатків за умови їх спрямування у розвиток людського капіталу може стати каталізатором економічного відновлення у посткризовий період. 
У подальших дослідженнях доцільно дослідити соціальні аспекти впливу пандемії на пенсійне забезпечення та доступ до медичних послуг, що дозволить виявити можливі інституційні інструменти удосконалення соціальної політики.

\section{ЛІТЕРАТУРА}

1. Верховна Рада України. Про внесення змін до Закону України "Про Державний бюджет України на 2020 рік”: Закон України № 553-IX від 29.05.2020. URL: https://zakon.rada.gov.ua/ laws/show/553-IX\#Text.

2. Верховна Рада України. Про державні соціальні стандарти та державні соціальні гарантії: Закон України № 2017-III від 05.10.2000. Редакція від 10.06.2018. URL: https://zakon.rada.gov.ua/ laws/show/2017-14.

3. Гнатенко К. В. Єдність і диференціація основа соціального забезпечення / Гнатенко К. В. // Науковий вісник Міжнародного гуманітарного університету. - 2019. - № 38. - С. 115-118.

4. Гнидюк I. В. Бюджетне фінансування соціального забезпечення в Україні / Гнидюк I. В., Гайдей О. В. // Науковий вісник Полтавського університету економіки і торгівлі. - 2018. - № 4 (89). C. 67-72.

5. Державна служба статистики України. Макроекономічні показники.

URL:

http://www.ukrstat.gov.ua/.

6. Кудлаєнко С. В. Структурні елементи механізмів реалізації соціальної політики / Кудлаєнко С. В. // Вісник Хмельницького національного університету. - 2019. - № 1. - С. 169-173.

7. Міжнародна організація праці. Конвенція про основні цілі та норми соціальної політики. Дата набрання чинності для України: 10.12.2016. URL: https://zakon.rada.gov.ua/laws/show/993_016\#Text.

8. Міністерство соціальної політики України. Щомісячний звіт про просування робіт (Звітний період: квітень 2020 року). URL: https://www.msp.gov.ua/news/18707.html.

9. Міністерство фінансів України. Видатки держбюджету України. URL: https://index.minfin.com.ua/ua/finance/budget/gov/exp ense/2020/.

10. Міністерство цифрової інформації України. Кабмін підтримав постанову про створення Міжгалузевої ради з питань цифрового розвитку, цифрових трансформацій i цифровізації. URL: https://thedigital.gov.ua/news/uryad-pidtrymavstvorennya-mizhhaluzevoyi-rady-z-pytan-tsyfrovohorozvytku-tsyfrovykh-transformatsiy-i-tsyfrovizatsiyi.

11. Насібова О. В. Теоретичні аспекти фінансового забезпечення соціального захисту населення / Насібова О. В. // Економіка та держава. - 2019. № 8. - С. 35-40.

12. Роледерс В. В. Проблеми фінансування сфери соціального захисту населення в Україні та шляхи їх подолання / Роледерс В. В., Кукель Г. С. // Інвестиції: практика та досвід. - 2019. - № 10. C. $49-54$.
13. Свидрук I. I. Управління конфліктами та соціальними експектаціями в діяльності організацій / Свидрук I. I. // Науковий вісник НЛТУ України. 2019. - Вип. 29 (9). - С. 98-107. URL: https://nv.nltu.edu.ua/index.php/journal/ article/view/2079.

14. Яригіна Є. П. Право сімей із дітьми на соціальний захист як складова соціальних прав людини і громадянина: вітчизняний і європейський контекст / Яригіна С. П. // Проблеми законності. 2019. - № 145. - C. 118-128.

15. Human Development Report 2019. United Nations Development Programme. URL: http://hdr.undp.org/en/data/explorer.

16. United Nations. International Definition and Measurement of Levels of Living: An Interim Guide. New York: United Nations, 1961. - 23 p.

\section{REFERENCES}

1. Verkhovna Rada Ukrainy. Pro vnesennia zmin do Zakonu Ukrainy "Pro Derzhavnyj biudzhet Ukrainy na 2020 rik": Zakon Ukrainy № 553-IX vid 29.05.2020, available at: https://zakon.rada.gov.ua/laws/show/553-IX\#Text.

2. Verkhovna Rada Ukrainy. Pro derzhavni sotsial'ni standarty ta derzhavni sotsial'ni harantii: Zakon Ukrainy № 2017-III vid 05.10.2000. Redaktsiia vid 10.06.2018, available at: https://zakon.rada.gov.ua/laws/show/2017-14.

3. Hnatenko, K. V. (2019), Yednist' i dyferentsiatsiia - osnova sotsial'noho zabezpechennia, Naukovyj visnyk Mizhnarodnoho humanitarnoho universytetu, № 38, s. 115-118.

4. Hnydiuk, I. V. and Hajdej, O. V. (2018), Biudzhetne finansuvannia sotsial'noho zabezpechennia v Ukraini, Naukovyj visnyk Poltavs'koho universytetu ekonomiky i torhivli, № 4 (89), s. 67-72.

5. Derzhavna sluzhba statystyky Ukrainy. Makroekonomichni pokaznyky, available at: http://www.ukrstat.gov.ua/.

6. Kudlaienko, S. V. (2019), Strukturni elementy mekhanizmiv realizatsii sotsial'noi polityky, Visnyk Khmel'nyts'koho natsional'noho universytetu, № 1, s. 169-173.

7. Mizhnarodna orhanizatsiia pratsi. Konventsiia pro osnovni tsili ta normy sotsial'noi polityky. Data nabrannia chynnosti dlia Ukrainy: 10.12.2016, available at: https://zakon.rada.gov.ua/laws/show/993_016\#Text.

8. Ministerstvo sotsial'noi polityky Ukrainy. Schomisiachnyj zvit pro prosuvannia robit (Zvitnyj period: kviten' 2020 roku), available at: https://www.msp.gov.ua/news/18707.html.

9. Ministerstvo finansiv Ukrainy. Vydatky derzhbiudzhetu Ukrainy, available at: https://index.minfin.com.ua/ua/finance/budget/gov/exp ense/2020/.

10. Ministerstvo tsyfrovoi informatsii Ukrainy. Kabmin pidtrymav postanovu pro stvorennia Mizhhaluzevoi rady $\mathrm{z}$ pytan' tsyfrovoho rozvytku, tsyfrovykh transformatsij i tsyfrovizatsii, available at: https://thedigital.gov.ua/news/uryad-pidtrymav- 
Herald of Lviv University of Trade and Economics. Economic Sciences. № 59, 2020

stvorennya-mizhhaluzevoyi-rady-z-pytan-tsyfrovohorozvytku-tsyfrovykh-transformatsiy-i-tsyfrovizatsiyi.

11. Nasibova, O. V. (2019), Teoretychni aspekty finansovoho zabezpechennia sotsial'noho zakhystu naselennia, Ekonomika ta derzhava, № 8, s. 35-40.

12. Roleders, V. V. and Kukel', H. S. (2019), Problemy finansuvannia sfery sotsial'noho zakhystu naselennia $\mathrm{v}$ Ukraini ta shliakhy ikh podolannia, Investytsii: praktyka ta dosvid, № 10, s. 49-54.

13. Svydruk, I. I. (2019), Upravlinnia konfliktamy ta sotsial'nymy ekspektatsiiamy v diial'nosti orhanizatsij, Naukovyj visnyk NLTU Ukrainy, vyp. 29 (9), s. 98-107, available at: https://nv.nltu.edu.ua/ index.php/journal/ article/view/2079.
14. Yaryhina, Ye. P. (2019), Pravo simej iz dit'my na sotsial'nyj zakhyst iak skladova sotsial'nykh prav liudyny i hromadianyna: vitchyznianyj i ievropejs'kyj kontekst, Problemy zakonnosti, № 145, s. 118-128.

15. Human Development Report 2019. United Nations Development Programme, available at: http://hdr.undp.org/en/data/explorer.

16. United Nations. International Definition and Measurement of Levels of Living: An Interim Guide (1961), United Nations, New York, 23 p.

Стаття надійшла до редакиії 13 березня 2020 року 